TARZYCJUSZ BULIŃSKI

Uniwersytet Gdański

\title{
Antropologia: metoda, teoria, doświadczenie osobiste
}

\begin{abstract}
Cyym jest antropologia? Metodą? Modelem poznania? Sposobem życia? Odpowiedzi są rzecz jasna rozmaite i nawiązuję do nich nieprzypadkowo, albowiem drugi tom „Etnografii” przepajają trzy wątki do nich się odnoszące. Skrótowo można je określić jako: 1) pytanie o specyfikę sposobu poznania $\mathrm{w}$ antropologii, która wpływa na tożsamość dyscypliny, 2) pytanie o teorie pozwalające przekraczać granice dyscypliny oraz 3) pytanie o rolę i wagę doświadczenia osobistego $\mathrm{w}$ antropologii.
\end{abstract}

Zacznijmy od kwestii wpływu metody etnograficznej na tożsamość dyscypliny. Dyskusja to rzecz jasna nienowa, w „Etnografii” zyskuje następny przyczynek w postaci tekstu Łukasza Kaczmarka pt. Między survey research a obserwacja uczestniczaca: rozdarcia metodologiczno-tożsamościowe w polskiej etnologii/antropologii kulturowej w XXI wieku. Autor przedstawia w nim swoją opinię na temat metodologicznej świadomości środowiska polskich antropologów i etnologów. Stawia mocną i zapewne nieco kontrowersyjną tezę o prymacie w polskiej etnografii badań typu survey research (bardziej sformalizowanych, np. wywiad kwestionariuszowy) nad badaniami opartymi na uczestniczeniu (mniej sformalizowanych, np. obserwacja uczestnicząca). Kaczmarek wskazuje, iż w Polsce niesłusznie za rdzeń etnografii uznano badania typu survey research, podczas gdy fundatorzy nowoczesnej antropologii, z Bronisławem Malinowskim na czele, jądra etnografii upatrywali (i upatrują nadal) w praktykach badawczych umożliwiających uczestniczenie etnografa $\mathrm{w}$ życiu badanych społeczności. Ta rozbieżność znacząco przyczyniła się do sytuacji, w której antropologia w Polsce - wg autora musi „,udowadniać” swoją metodologiczną naukowość przed przedstawicielami nauk posługującymi się bardziej sformalizowanymi technikami, np. psychologami czy socjologami. A to z kolei pociąga za sobą szereg trudności instytucjonalnych i organizacyjnych, przed którymi stają dziś polscy adepci antropologii.

Tekst Kaczmarka opatrujemy komentarzami dwóch ważnych postaci polskiej antropologii, które na problem przywołany przez autora spojrzały poprzez 
pryzmat swoich bogatych doświadczeń i szerokiej wiedzy metodologicznej. Zofia Sokolewicz, jedna z kluczowych osób dla rozwoju etnologii w Polsce, w tekście pt. Badania terenowe jako gwarancje empiryzmu antropologii? ujęła kwestię wpływu metody na tożsamość antropologii w szerszym kontekście, odnosząc się do swego ogromnego doświadczenia naukowego. I pokazała, że pytanie Kaczmarka jest współczesnym wariantem pytań istniejących już wcześniej w obrębie dyscypliny. Za każdym razem poszczególne rewolucje teoretyczne obiecywały „ziemię obiecaną" poznania Innych, która okazywała się tą ",wyśnioną" tylko przez czas jakiś, aż do następnego "przewrotu”. Wskazała, że rozważania na temat metod są zawsze zakotwiczone $\mathrm{w}$ modelu nauki tkwiącym $\mathrm{u}$ ich podstawy, więc rozważania na temat survey research i obserwacji uczestniczącej są w rzeczywistości rozmową o modelu uprawiania antropologii. I stąd też rozbieżności w pojmowaniu etnograficznych sposobów badania w różnych okresach historycznych. Zaś to, co wydaje się wiodącym motywem naszych czasów, to idea doświadczania, upodmiotowienia badanych i zażyłości z nimi (uobecniana w tekście Kaczmarka ideą obserwacji uczestniczącej).

Andrzej Paweł Wejland w tekście pt. Siedem ideałów, korzystając ze swej znajomości metod zarówno antropologii, jak i nauk jej pokrewnych, precyzyjnie sytuuje kwestię postawioną przez Kaczmarka w kontekście współczesnej metodologii nauk społecznych. Ujmuje ją za pomocą siedmiu metodologicznych ideałów, do których osiągnięcia zwykle dążymy. Dzięki temu zagadnienie postawione przez Kaczmarka przedstawia w nowym porządku, proponuje jego częściową korektę, lecz nie uchyla samego pytania i - co najważniejsze - samej dążności do jego zadania. Podtrzymuje więc wartość pytania o to, jak coś należy robić. Warto więc pytać nie tylko o to, ,jak badać?", ale także i o to, jak to robić antropologicznie, i czy antropologiczny sposób poznania w ogóle istnieje, a jeśli tak, to na czym polega jego specyfika? Troska o ideały tego, jak coś robimy, wydaje się ciągle aktualna.

Sądzę, że pytanie zawarte w tekście Kaczmarka jest ważne, a pokoleniowo wręcz niezbędne. Kim jesteśmy my, polskie antropolożki, polscy antropologowie? (A może etnografki i etnografowie?) Co buduje naszą tożsamość? Gdzie wyznaczamy naszą granicę? Ci, którzy więcej doświadczyli, więcej wiedzą i rozumieją (Sokolewicz, Wejland), mówią nam, że warto o to pytać, nie dlatego, żeby dojść do prawdy, lecz po to, aby poznać siebie. Czy nasze pokolenie to ukształtowane w czasie transformacji systemowej przełomu wieków (lata 90. XX w. i pierwsza dekada XXI w.) - przyswoiło teoretyczną różnorodność humanistyki przełomu wieków, lecz na poziomie badań etnograficznych używa technik surveyopodobnych zbudowanych dla innej epoki i dla innego modelu nauki? A może survey research naszych czasów jest inny? Może jest metodologicznie odrębny względem tego, czego uczyliśmy się na studiach? Jak nieobecność w polskiej etnologii tradycji intensywnych badań terenowych (które realizowało bardzo niewiele osób) wpłynęła na to, kim jesteśmy? Czemu nie mamy współczesnych polskich książek o doświadczeniu terenowym? Jedynie publikacje Kazimiery Zawistowicz-Adamskiej i długo długo nic? A może nie są one nam 
potrzebne? Agnieszka Halemba (2011) opisywała, jak na studiach w Anglii, a potem w czasie badań na Syberii, musiała wręcz odzwyczajać się od prowadzenia surveyu. Ale czy nie jest to także swego rodzaju mit? Obraz ukuty właśnie na podstawie naszej edukacji, lektur w stylu Rabinowa czy Barleya? Mit, który zderza ze sobą światy technik sformalizowanych i niesformalizowanych? Mit, który jest ważny dla budowania tożsamości właśnie, ale nie przekłada się na praktykę badawczą? Jest przecież już wielu polskich młodych badaczy wykształconych w anglosaskim czy frankofońskim systemie akademickim. Czy dla nich także tego rodzaju dychotomie coś wnoszą dla sprawy? Czy pomagają $\mathrm{w}$ definiowaniu siebie, swoich badań, projektów, książek? Jestem pewien, że takie pytania warto zadawać. Nasze pokolenie nie przeżyło takich gorących dyskusji, o których wspomina Sokolewicz. Ostatnią wielką debatą w polskiej antropologii był postmodernizm lat $90 . \mathrm{XX}$ wieku. Teraz trochę czekamy. Inne sprawy wybijają się na plan pierwszy: wymogi administracyjne, finansowanie, granty... Owszem, czasami dyskutujemy. O antropologii zaangażowanej, o miejscu antropologii $w$ życiu publicznym, o etnografii opartej na współpracy. Ale wydaje się, że - jak na razie - nie zajmują one centralnego miejsca w świadomości i praktykach polskich antropologów. Nie "zmuszają" każdego z nas do zajęcia stanowiska w wytyczonych przez nie szrankach. Można działać i myśleć poza nimi. Być może jeszcze nie czas...

Mam nadzieję, że zarówno tekst Kaczmarka, jak i komentarze sytuujące go w szerszym kontekście będą stanowić zachętę do osobistego wypowiedzenia się w tym względzie. Gorąco do tego namawiam.

Przejdźmy teraz do drugiego wątku, tj. do teorii pozwalających przekraczać granice dyscypliny, teorii będących inspiracją. To ważny wątek $w$ definiowaniu antropologii. Nieprzypadkowo w jej tradycji nader chętnie przywoływane są wszelkiego rodzaju metafory obrazujące antropologię jako gałąź wiedzy notorycznie przekraczającą granice dyscyplinarne i poszukującą inspiracji wszędzie tam, gdzie tylko to możliwe. Antropologia jako kłusownictwo intelektualne (Clyde Kluckhohn), antropologia jako przekładanie jednych form życia na drugie (Clifford Geertz) to tylko te najbardziej znane metafory. My antropolodzy lubimy definiować samych siebie jako otwartych pod wieloma względami.

Dlatego też ważny wydaje mi się fakt, że w niniejszym tomie „Etnografii” pojawiły się dwa teksty odnoszące się do koncepcji teoretycznych stosunkowo mało obecnych w polskiej antropologii, a które wydają się w niej nader potrzebne. Myślę tu o koncepcji Michela Foucaulta oraz o propozycji teoretycznej Tima Ingolda. Obaj myśliciele są sytuowani w odrębnych paradygmatach myślowych i obaj też dostarczają odmiennych narzędzi do badania świata, tym niemniej łączy ich jedno - obaj z łatwością przekraczają granice dyscyplinarne, oferując w swych pracach przebogate instrumentarium poznawcze dla adeptów różnych gałęzi wiedzy. 
Sytuacja ich recepcji w polskiej antropologii jest odmienna. O ile myśl Foucaulta jest dobrze rozpoznana na poziomie teoretycznym i pojawia się często przy okazji analiz koncepcji oraz problemów ogólnych, to została ona prawie zupełnie zarzucona, jeśli chodzi o zastosowania praktyczne odnośnie do analiz samego materiału terenowego oraz wywołujących go narzędzi badawczych ${ }^{1}$. Wydaje się, że w polskiej antropologii koncepcja Foucaulta jest blisko stania się teorią klasyczną, tj. taką, którą znają i cytują wszyscy, lecz mało kto ją stosuje w konkretnych zagadnieniach metodologicznych i terenowych. Tę lukę próbuje wypełnić tekst Filipa Wróblewskiego pt. Kwestionariusze etnograficzne i prawo zadawania pytań. Autor przy użyciu kategorii Foucaulta, Flussera i Goody'ego analizuje okoliczności powstania i konsekwencje funkcjonowania klasycznego narzędzia badawczego etnografów - kwestionariusza. Opisuje, jak to narzędzie $\mathrm{w}$ niejawny sposób wypływało na samych badaczy, badanych oraz uzyskiwaną wiedzę (na proces jej wywoływania, konceptualizowania i porządkowania). Słowem, jak technika badawcza zwrotnie wpływała na metodologię, a nawet i na epistemologię. Kwestionariusz w ujęciu Wróblewskiego przestaje być neutralnym narzędziem, a staje się medium, z całym bogactwem semantycznym i epistemologicznymi konsekwencjami tego terminu. Tekst ten tworzy interesujący dwugłos z omówionym powyżej artykułem Kaczmarka traktującym przecież właśnie o badaniach z użyciem kwestionariuszy (survey research).

A że jest to trop obiecujący potwierdza inny tekst $\mathrm{w}$ tym tomie autorstwa Marcina Gołębia pt. Tony papierów, tomy analiz. O biedzie, urzędnikach i biurokracji w Indiach, będący krytycznym omówieniem książki Akhila Ghupty Red Tape. Bureaucracy, Structural Violence, and Poverty in India. W pracy tej funkcjonowanie administracji państwowej w Indiach przełomu XX i XXI wieku oraz jej wpływ na życie najuboższych grup społeczeństwa indyjskiego jest badane za pomocą koncepcji Foucaulta. Warto też zauważyć, że jeden z ostatnich numerów „Przeglądu Socjologii Jakościowej" został poświęcony właśnie temu myślicielowi (Nowicka, Franczak 2016).

Recepcja Ingolda wygląda nieco inaczej, gdyż zdaje się on na razie „wielkim nieobecnym" w polskiej antropologii. Oczywiście jego nazwisko pojawia się w niektórych pracach i jest nierzadko przytaczane, ale zastanawia fakt nieobecności projektów badawczych, które by bezpośrednio nawiązywały lub operowały kategoriami ingoldowskimi. Brakuje zresztą nie tylko przekładów prac Ingolda, ale także zwartych omówień jego dorobku. W chwili gdy na polskim rynku wydawniczym jest już obecnych wiele dzieł Clifforda Geertza, Marshalla Sahlinsa czy Pierre'a Bourdieu, gdy mamy nawet przekład jednej $\mathrm{z}$ ostatnich prac Jean i Johna Comaroff, to Ingolda w dalszym ciągu możemy poznać wyłącznie we fragmentach (Ingold 2003, 2012, 2014, 2015a, 2015b; Ingold, Hallman 2014; zob. też Wala, Zych 2014). Musi to dziwić, zważywszy na olbrzy-

1 Jednym z nielicznych przykładów zastosowania myśli Foucaulta w rodzimej antropologii jest niepublikowana praca doktorska Katarzyny Kubat (2012). 
mią skalę i różnorodność dokonań badawczych tego antropologa, które sytuują go pośród najważniejszych postaci współczesnej antropologii.

Cykl tekstów Katarzyny Wali jest najprawdopodobniej pierwszą polską próbą całościowego przybliżenia propozycji teoretycznych Tima Ingolda (tzw. późnego Ingolda). $\mathrm{Z}$ racji wielkości dorobku tego badacza omówienie to zostało podzielone na trzy artykuły, które będą prezentowane w kolejnych tomach czasopisma. Obecny w niniejszym numerze tekst Ułożyć świat na nowo. Rekonstrukcja koncepcji Tima Ingolda (cz. I) jest wprowadzeniem do ingoldowskiej koncepcji środowiska i elementów tworzących jego tkankę, tj. pogody i rzeczy. W drugim artykule omówiona zostanie koncepcja uzmysłowionego organizmu i jego percepcji oraz kategorie produkcji, historii, zamieszkiwania i linii. Oba te teksty są niezbędnym wprowadzeniem teoretycznym do trzeciego artykułu, w którym - na przykładzie etnografii sensorycznej - będą rozważone możliwości zastosowania tej koncepcji w badaniach terenowych. Wierzę, że tak przeprowadzona rekonstrukcja przyczyni się do szerszego zaistnienia myśli ingoldowskiej w polskiej antropologii i dostarczy zarówno inspiracji, jak i konkretnych narzędzi poznawczych dla na nowo pomyślanych badań etnograficznych.

\section{III}

Trzeci wątek w „Etnografii” dotyczy refleksywności antropologa i zarazem jego emocjonalnego zaangażowania w praktykę antropologiczną, która czasami niepostrzeżenie przeobraża się w sposób życia. Ten wątek wprowadza w bardzo osobisty, a zarazem literacko spełniony sposób, tekst Sylwii Pietrowiak pt. Błędne koło błazna, czyli krok wstecz z letniej kuchni Gulnary. To nietypowy tekst. Zwykle bowiem antropolodzy opisują swoje doświadczenia osobiste, zamykając je w ramy „doświadczenia terenowego", gdzie służą im jako pomoc w rozważaniach naukowych. Badacze w tekstach raczej „odchodzą od siebie”, niźli się „do siebie zbliżają" - przytaczają książki, cytują rozmówców, budują teoretyczne modele, próbując wpasować w nie "potok” życia, którego doświadczyli, rzadko dzieląc się tym, co przeżyli i co odczuli. W rezultacie teksty antropologiczne są czymś odległym od tego, co pamięta nasze ciało i umysł. Doświadczenie rychło przeobraża się $\mathrm{w}$ anegdotę, opowieść opowiadaną na sali wykładowej czy nawet podczas występów w pubie, jak zjadliwie zauważa Geertz (2000), pisząc o Edwardzie Evans-Pritchardzie. Inaczej mówiąc, to, co żywotne i egzystencjalne przekształca się w narrację rządzącą się swoim regułami i wykorzystywaną do budowy naszego autorytetu etnograficznego à la James Clifford. Tymczasem Pietrowiak decyduje się podzielić (to słowo wydaje mi się tu najwłaściwsze) swoimi odczuciami i wątpliwościami, kwestiami, których typowy tekst naukowy jest pozbawiony. Albowiem wbrew deklaracjom znacznej części antropologów, że model pozytywistyczny pozostawiliśmy za sobą, w myśleniu i pisaniu jest on ciągle obecny i dążność do unaukowienia naszej działalności nie zanika. Dlatego też ujęcie zaproponowane przez Pietrowiak wydaje się ciekawą alternatywą wobec aktualnych kanonów pisarstwa antropologicznego. Na plan pierwszy wybijają 
się w nim refleksywność, emocje i myśli zawarte w przeżytych sytuacjach oraz poczucie poznawczej i etycznej niepewności. Wszystko to razem dobrze oddaje, czym antropologia bywa, gdy pozbawimy ją naukowej lub podróżniczej narracji, a zostawimy samo doświadczenie konkretnego człowieka. Jest przeżyciem, które miast prawdy oferuje autentyczność.

Artykuł Pietrowiak w niezamierzony sposób uzupełniają fragmenty obecne $\mathrm{w}$ dwóch tekstach umiejscowionych $\mathrm{w}$ innych działach czasopisma. Pierwszy $\mathrm{z}$ nich to tekst Jędrzeja Lichoty pt. Inna strona ludowej muzyki (dziennik terenowy fragmenty), osoby dopiero stawiającej pierwsze kroki na antropologicznej drodze. Widać w nim, jak tworzyło się doświadczenie terenowe autora, widać zmagania ze sobą i innymi ludźmi, dialogiczność doświadczenia antropologa, nienaturalność technik badawczych (kwestionariusz!) skontrastowaną z tym, co jest istotą tzw. badań terenowych - kontaktem $\mathrm{z}$ inną osobą, którego nie da się zaplanować i skontrolować. $Z$ kart dziennika od czasu do czasu wyzierają emocje i nieprzewidziane interakcje. W mikroskali widać w nim to, co w dojrzałej formie pojawia się w tekście Pietrowiak - etnografia jest spontanicznym, emocjonalnym spotkaniem odległych od siebie osób o niedających się przewidzieć konsekwencjach. Spotkanie to jest pełne niewiadomych dla obu stron i nie przynosi kojących rozstrzygnięć poznawczych i emocjonalnych. Jest jednak ruchem, który zmienia osoby biorące w nim udział i powoduje przeobrażenia osobiste. Puentę zaś przynosi tekst Zofii Sokolewicz, o którym już była mowa przy okazji artykułu Kaczmarka. Badaczki, której doświadczenie naukowe i życiowe wielokrotnie przewyższa doświadczenia Lichoty, Pietrowiak czy moje własne. Profesor kończy swoją refleksję na temat metody etnograficznej przeniesieniem kwestii naukowych na poziom osobisty i bezpośredni. „Nazywam się jak się nazywam i robię to, co robię" brzmi ostatnie zdanie. Trudno o lepszy komentarz. Antropologia, czymkolwiek jest i czymkolwiek mogłaby być, jest w pierwszym rzędzie życiem konkretnej osoby. Jej losem i wyborem.

Oprócz artykułów poruszających trzy powyższe wątki drugi numer „Etnografii” zawiera także inne teksty. Przede wszystkim są to artykuły relacjonujące efekty badań terenowych obiecujących młodych badaczy. Na plan pierwszy wybijają się tu teksty sytuujące się $\mathrm{w}$ ramach szeroko rozumianej antropologii medycznej. Justyna Szymańska w artykule pt. Wiara, nadzieja, autorytet. Praktyki uzdrowicielskie na Podolu Wschodnim przygląda się dzisiejszemu funkcjonowaniu medycyny komplementarnej na Ukrainie. Pokazuje praktyki uzdrowicielskie poprzez pryzmat ich miejsca w życiu pacjentów, strategii stosowanych przez uzdrowicieli oraz medycyny oficjalnej związanej z instytucją państwa. Szczególnie warty uwagi jest sposób, w jaki autorka przedstawia sprawczość ludzi praktykujących medycynę komplementarną i to zarówno uzdrowicieli, jak i osób leczących się. Z kolei Karolina Kuberska w tekście pt. Sobreparto and the lonely childbirth: Postpartum illness and embodiment of emotions among Andean migrants in Santa Cruz de la Sierra, 
Bolivia przedstawia zespół chorobowy pojawiający się po porodzie wśród kobiet - migrantek w Santa Cruz w Boliwii. Autorka poszerza klasyczne etnograficzne ujęcie tej choroby o jej wymiar społeczny, w którym indywidualne dolegliwości cielesne są połączone $\mathrm{z}$ niedostatkami więzów społecznych i poczuciem osamotnienia w czasie porodu i połogu. Godny uwagi jest sposób, w jaki Kuberska umiejscawia doświadczenia choroby w szerszym kontekście społecznym - wychodzi od indywidualnych narracji, by analizę zakotwiczyć $w$ realiach codziennego życia migrantów z gór, w jego niedostatkach społecznych i emocjonalnych, czy wreszcie w procesach konstruowania tego, co dla bohaterek tekstu oznacza być kobietą, matką czy krewną.

Inną tematykę porusza Piotr Hus w tekście Wspólnota znaczeń czy nowoplemię? Etnograficzne badania warszawskiej społeczności couchsurfingowej. Autor zajmuje się w nim na wskroś współczesnym tematem turystyki alternatywnej, czyli podróżowania z noclegami u osób, które bezpłatnie udostępniają swój dom i czas, dzięki czemu podróżnik ma okazję poznać odwiedzane miejsca „oczami" ludzi mieszkających tam na co dzień. Hus przybliża nam wiele aspektów społeczności, jaka powstała wokół portalu internetowego Couchsurfing. Nie ogranicza się przy tym do jej statycznego obrazu, pokazując nam przeobrażenia, jakim podlega ona na przestrzeni ostatnich lat. To dobry przykład, jak powinny wyglądać rzetelne badania etnograficzne i oparty na nich tekst.

$\mathrm{Z}$ kolei artykuł Ewy Hübner pt. Wypisywanie życia. Etnograficzne spotkanie $z$ Waleria Prochownik - pisarka z żywieckiego Sporysza jest autorskim zastosowaniem idei etnografii opartej na współpracy Luke'a Lassitera. Tekst dotyczy poszukiwania tego, czym jest pisanie poezji i prozy pisarki ludowej - Walerii Prochownik - dla niej samej oraz dla autorki tekstu. Jest to więc próba urzeczywistnienia etnografii, której naczelną cechą jest dialog i dążenie do wypracowania sensu zdarzeń akceptowanego przez osoby o odmiennych perspektywach i doświadczeniach. Warte zauważenia jest konsekwentne unikanie przez Hübner przyjmowania w tekście postawy , ,ja wiem lepiej" - artykuł nie oferuje prostych odpowiedzi, choć niewątpliwie przybliża Czytelnikowi punkty widzenia i przeżywania obu stron spotkania.

Osobną kwestią jest tekst JoAnn D'Alisera pt. Teren marzeń. Antropolog daleko od domu. Jest to pierwszy przekład tekstu obcojęzycznego w „Etnografii” autorstwa Michała Żerkowskiego. Zdecydowaliśmy się na ten tekst z kilku względów. Po pierwsze, dlatego że zgrabnie wprowadza on problematykę antropologii u siebie (anthropology at home), z którą mierzy się większość polskich studentów antropologii prowadzących przecież badania u siebie, a nie w Afryce czy Nowej Gwinei. D'Alisera zmaga się z mitem „prawdziwych badań terenowych”, które powinny być prowadzane gdzieś daleko, najlepiej w afrykańskiej wiosce. Opisuje swoje rozterki, zwątpienia i trudności, gdy okazało się, że jej klasyczny projekt badań terenowych wśród ludu Susu w Sierra Leone się nie powiódł. I gdy postanowiła ten sam problem przebadać u siebie, w Waszyngtonie, wśród imigrantów z Sierra Leone. Pytania, które sobie zadawała (np. „Czy można powadzić intensywne badania terenowe u siebie?" „Czy wspólne oglądanie oper mydlanych 
w telewizji jest już badaniem terenowym?"), nie będą nam obce i wielu z nas się z nimi stykało we własnej praktyce badawczej. Po drugie, dlatego że artykuł wprowadza potrzebne dzisiaj zagadnienia $\mathrm{z}$ zakresu antropologii transnarodowych. Kłopot metodologiczny autorki („Gdzie szukać terenu badań?” „Czy da się odnaleźć u siebie konkretną namacalną społeczność ludzi, którą można umiejscowić w przestrzeni, nadać jej granice?") jest znany wszystkim, którzy podejmują temat społeczności mobilnych, rozdzielonych przestrzenią, miejscem życia, lecz podobnych praktykami kulturowymi i bliskością społeczną. Warto zatem się przyjrzeć, w jaki sposób D'Alisera "odkryła" teren w swoim otoczeniu, jak to, co jej znane zaczęło nabierać innych sensów, stawać się obcym i nierozpoznanym. Warto też prześledzić jej zadziwienia tym, jak ludzie z innej kultury mogą używać tych samych technicznych narzędzi, takich jak np. telefon komórkowy. Pytanie, które sobie stawia, wydaje się zasadne i żywotne: „Czy można uczestniczyć w obcej kulturze, nie mówiąc już o jej obserwowaniu, za pomocą kabla telefonicznego?". I po trzecie wreszcie, Teren marzeń został napisany lekkim stylem ułatwiającym jego przyswojenie, pozwala to na prawdziwą „przyjemność lektury". Czytelnik może zapoznać się niejako „od kuchni" z praktyką prowadzenia etnograficznych badań terenowych. W artykule jest sporo szczegółów praktycznych, takich jak organizowanie transportu, szukanie właściwych rozmówców, uzgadnianie projektu badań na uczelni itp., a więc kwestii, o których zazwyczaj teksty antropologiczne nie wspominają. Sądzę, że może stać się wartościową lekturą wykorzystywaną na zajęciach dydaktycznych dotyczących etnografii czy antropologii transnarodowych.

Drugi numer „Etnografii” dopełniają trzy teksty recenzyjne. Dwa pierwsze mieszczą się w szeroko rozumianej antropologii piśmienności oraz antropologii biurokracji. Justyna Schollenberger w tekście pt. Wtadza (z) papieru - sposoby działania dokumentów pakistańskiej biurokracji wyczerpująco przybliża nam książkę Matthew Hulla Government of Paper. The Materiality of Bureaucracy in Urban Pakistan, będącą błyskotliwą analizą antropologiczną funkcjonowania biurokracji państwowej w Pakistanie. Z kolei wspominany już tekst Marcina Gołębia Tony papierów... krytycznie omawia książkę Akhila Ghupty Red Tape dotyczącą podobnej problematyki - relacji pomiędzy administracją państwową w Indiach a najuboższymi grupami społeczeństwa indyjskiego przełomu XX i XXI wieku. Nieco zbliżoną tematyką zajmuje się też Agata Agnieszka Konczal w tekście pt. W cieniu Białowieskiej Puszczy. Studium z antropologii ekologicznej. Opowiada w nim o pracy Eunice L. Blavascunas The peasant and communist past in the making of an ecological region referującej badania przeprowadzone na polskim Podlasiu i obrazującej splot czynników ekologicznych, kulturowych i gospodarczych wpływających na politykę społeczną państwa wobec ludzi i przyrody tego regionu.

Całość numeru zamyka sprawozdanie $\mathrm{z}$ badań terenowych prowadzonych przez Aleksandrę Paprot, które przybliża w tekście pt. Kreowanie tożsamości regionalnej oraz lokalnej na Ziemiach Zachodnich i Pótnocnych (ze szczególnym uwzględnieniem Żuław i Powiśla) - relacja z badań. 


\section{Literatura}

Geertz, C. (2000). Dzieło i życie. Antropolog jako autor. Przeł. E. Dżurak, Sł. Sikora. Warszawa: Wydawnictwo KR.

Halemba, A. (2011). Polityka, teoria, antropologia - czyli co tworzy współczesną antropologię. W: T. Buliński, M. Kairski (red.), Teren w antropologii. Praktyka badawcza we wspótczesnej antropologii kulturowej (s. 111-130). Poznań: Wydawnictwo Naukowe UAM.

Kubat, K. (2012). Dyskurs szaleństwa kobiet na podstawie polskich podręczników psychiatrii 1845-2003, praca doktorska w archiwum UJ, Uniwersytet Jagielloński.

Ingold, T. (2003). Kultura i postrzeganie środowiska. Przeł. G. Pożarlik. W: M. Kempny, E. Nowicka (red.), Badanie kultury. Elementy teorii kultury (s. 73-86). Warszawa: Wydawnictwo Naukowe PWN.

Ingold, T. (2012). Materiały przeciwko materialności. Przeł. M. Wawrzyńczak. W: K. Gutfrański, A. Hendriks, I. Moreiry, A. Szyłek, L. Vergary (red.), Materialność (s. 95-125). Gdańsk: Instytut Sztuki Wyspa.

Ingold, T. (2014). ",Człowieczyć” to czasownik. Przeł. E. Klekot. W: M. Buchowski, A. Bentkowski (red.), Colloquia Anthropologica. Problemy wspótczesnej antropologii społecznej (s. 527-544). Poznań: Wyd. Nauka i Innowacje.

Ingold, T. (2015a). Rysowanie, pisanie i kaligrafia. Przeł. M. Rakoczy. Teksty Drugie, 4, 371-392.

Ingold, T. (2015b). O klockach i węzłach. Architektura jako tkanie. Przeł. M. Choptiany. Autoportet, 4(51), 34-35.

Ingold T., Hallam E. (2014). Twórczość i improwizacja kulturowa. Przeł. M. Rakoczy. W: G. Godlewski, A. Karpowicz, M. Rakoczy, P. Rodak (red.), Communicare: Almanach antropologiczny, t. IV. Twórczość stowna. Literatura. Performance, tekst, hipertekst (s. 15-24). Warszawa: Wyd. Uniwersytetu Warszawskiego.

Nowicka, M., Franczak, K. (red.). (2016). Perspektywa Foucaultowska we współczesnej refleksji badawczej. Przegląd Socjologii Jakościowej, 12(1).

Wala, K., Zych, M. (2014). Ruch, którym jesteśmy, zawiera też ruch naszych myśli z Timem Ingoldem rozmawiają Katarzyna Wala i Magdalena Zych. Autoportet, 2(45), 11-13.

\section{SUMMARY}

Anthropology: Method, theory, personal experience

This paper outlines three ways of understanding the specificity of cultural anthropology. The first one characterises the discipline by means of the method of understanding the world, i.e. ethnographic fieldwork. The second refers to a manner of thinking about the world, i.e. intellectual poaching and transgressing interdisciplinary boundaries. The third one shows anthropology as a way of life, foregrounding personal experience.

Keywords: cultural anthropology, identity, fieldwork, ethnographic experience, theory 